\title{
Penguatan Kapasitas Penyusunan Dokumen Reneana Pembangunan Desa
}

\author{
Arifuddin, La Ode Anto, Syamsir Nur, Nitri Mirosea \\ Fakultas Ekonomi dan Bisnis, Universitas Halu Oleo \\ Email: nitri.mirosea@uho.ac.id \\ DOI: $10.18196 / p p m .36 .319$
}

\begin{abstract}
Abstrak
Pandemi global membawa perubahan tatanan pada sektor perekonomian dan kehidupan sosial masyarakat. Kecamatan Konda (Sulawesi Tenggara) merupakan sentra UMKM disektor perdagangan hasil tanaman pangan, perkebunan serta industri olahan bahan makanan (BPS Konawe Selatan, 2019). Daerah ini merupakan rantai nilai utama dalam penyediaan bahan pangan, artinya warga desa yang berkarakter semi-urban sangat rawan dalam rantai penyebaran virus. Ruang intervensi pemerintah daerah hingga di level desa dalam pencegahan dan penanganan dampak Covid-19 dilakukan melalui refocusing dan realokasi anggaran termasuk dana desa. Tujuan dan output kegiatan pengabdian kepada masyarakat untuk membantu menyusun rencana pembangunan desa yang mengintegrasikan risiko ekonomi (kelangsungan usaha masyarakat desa) akibat pandemi Covid-19. Metode yang digunakan adalah Participatory Learning and Action. Hasil analisis situasi sosial melalui metode survei lapangan terdapat keterbatasan kemampuan aparatur desa menyusun rencana pembangunan jangka menengah desa (RPJMDes) serta anggaran pendapatan desa (APBDes) dalam upaya memitigasi risiko bencana dalam kondisi pandemi Covid-19. Fokus pembangunan desa pada infrastruktur seperti pengerasan jalan dan duiker sedangkan fasilitas kesehatan masih minim. Kegiatan dilakukan melalui knowledge sharing dan pelatihan penyusunan rencana anggaran pembangunan desa yang diikuti oleh aparatur dari 15 desa.
\end{abstract}

Kata Kunci: Penguatan Kapasitas, RPD

\section{Pendahuluan}

Pemerintah telah menetapkan status "Darurat Bencana Corona" di Indonesia hingga tanggal 29 Mei 2020. Hal ini dilakukan dalam rangka merespons penyebaran Covid-19 yang semakin meluas di berbagai belahan dunia, sekaligus mencegah penyebaran yang tidak terkendali di Indonesia. Akselerasi penangangan penyebaran Covid-19 terus dilakukan melalui belajar dari rumah (study from home), pelarangan kegiatan publik, serta bekerja dari rumah (work from home). Bahkan karantina wilayah pun telah diberlakukan oleh pemerintah pusat di sebagian wilayah di Indonesia (Pembatasan Sosial Berskala Besar/PSBB) mengingat jumlah pertambahan kasus positif terinfeksi corona yang terkonfirmasi yang terus meningkat dengan persentase kematian yang cukup tinggi. Per tanggal 20 Maret 2020 telah terdapat lebih dari 300 kasus positif terinfeksi virus corona dengan kasus meninggal sebanyak 25 pasien. Indonesia menempati urutan kedua setelah Singapura dalam hal jumlah kasus positif dengan angka dan persentase kematian yang paling tinggi (www.worldometers.info/coronavirus/).

Untuk merespons berbagai perkembangan situasi di atas, seluruh masyarakat Indonesia hendaknya mendukung upaya pemerintah pusat dan daerah untuk menekan laju peningkatan jumlah kasus Covid-19 di Indonesia, dengan melaksanakan pembatasan sosial dan melakukan isolasi mandiri di rumah. Bagi pelaku usaha, hal ini merupakan peristiwa disrupsi yang membawa aktivitas usaha tidak lagi berada dalam kondisi yang tidak normal (business as usual) yang tidak hanya industri diperkotaan tetapi juga memapar kegiatan usaha masyarakat di pedesaaan. Dalam hal ini 
hendaknya pemerintah daerah melakukan adaptasi dalam menerapkan perencanaan dan penganggaran yang dapat menopang kelangsungan usaha masyarakat (business continuity management). Ruang intervensi pemerintah daerah hingga di level desa dalam hal pencegahan dan penanganan dampak Covid-19 dilakukan melalui refocusing kegiatan dan realokasi anggaran termasuk dana yang dikelola oleh pemerintah desa.

Kecamatan Konda berlokasi di Kabupaten Konawe Selatan yang memiliki jumlah usaha/industri rumah tangga, kecil dan menengah yang umumnya bergerak disektor perdagangan hasil tanaman pangan dan perkebunan serta industri olahan bahan makanan (BPS Konawe Selatan, 2019). Dengan potensi ekonomi utama yaitu sektor pertanian dan perkebunan. Dari aspek ekonomi, aktivitas usaha masyarakat desa ini memasarkan hasil kebun untuk pemenuhan kebutuhan masyarakat Kota Kendari khususnya komoditas tanaman sayuran, perkebunan dan makanan pangan olahan (supply side); masyarakatnya dikategorikan berkarakter semi-urban dan memiliki kerawanan dalam rantai penyebaran virus (sisi kesehatan). Sebaliknya, pemenuhan kebutuhan warga desa diperoleh langsung dari pusat perbelanjaan di Kota Kendari (demand side). Selain permasalahan tersebut diatas, pemerintah desa memiliki problem spesifik perihal keterbatasan kemampuan aparatur desa dalam penyusunan rencana pembangunan jangka menengah desa (RPJMDes) serta anggaran dan pendapatan desa (APBDes), terutama dalam upaya memitigasi risiko bencana termasuk dalam kondisi pandemi Covid-19.Tujuan dari kegiatan pengabdian kepada masyarakat dalam bentuk KKN Tematik ini adalah untuk penguatan kapasitas dalam penyusunan rencana pembangunan desa dan penganggaran pembangunan secara adaptif serta warga dapat meningkatkan pengetahuan akan risiko pandemi Covid-19 yang diakibatkan oleh aktivitas ekonomi yang ditekuninya.

\section{Metode Pelaksanaan \\ Persiapan dan Pembekalan}

Pelaksanaan KKN tematik 2020 diawali dengan persiapan. Persiapan ini dilakukan dengan beberapa kegiatan yaitu: penentuan calon ketua dan anggota tim DPL, diskusi tentang topik KKN dan penyusunan proposal. Kegiatan persiapan tidak luput juga perumusan materi yang relevan dengan permasalahan pemerintah desa dan pelaku usaha/masyarakat semi-urban saat ini akibat pandemi Covid-19 dan menentukan nara sumber yang relevan dan berkompeten.

\section{Pelaksanaan}

Pelaksanaan KKN tematik 2020 terdiri dari lima tahapan mulai dari penentuan wilayah sasaran kegiatan, identifikasi desa sasaran kegiatan, perumusan metode penanganan masalah, pelaksanaan sosialisasi dan terakhir evaluasi dan penyusunan laporan. Tahapan kegiatan KKN tematik 2020 digambarkan dalam flow chart berikut: 


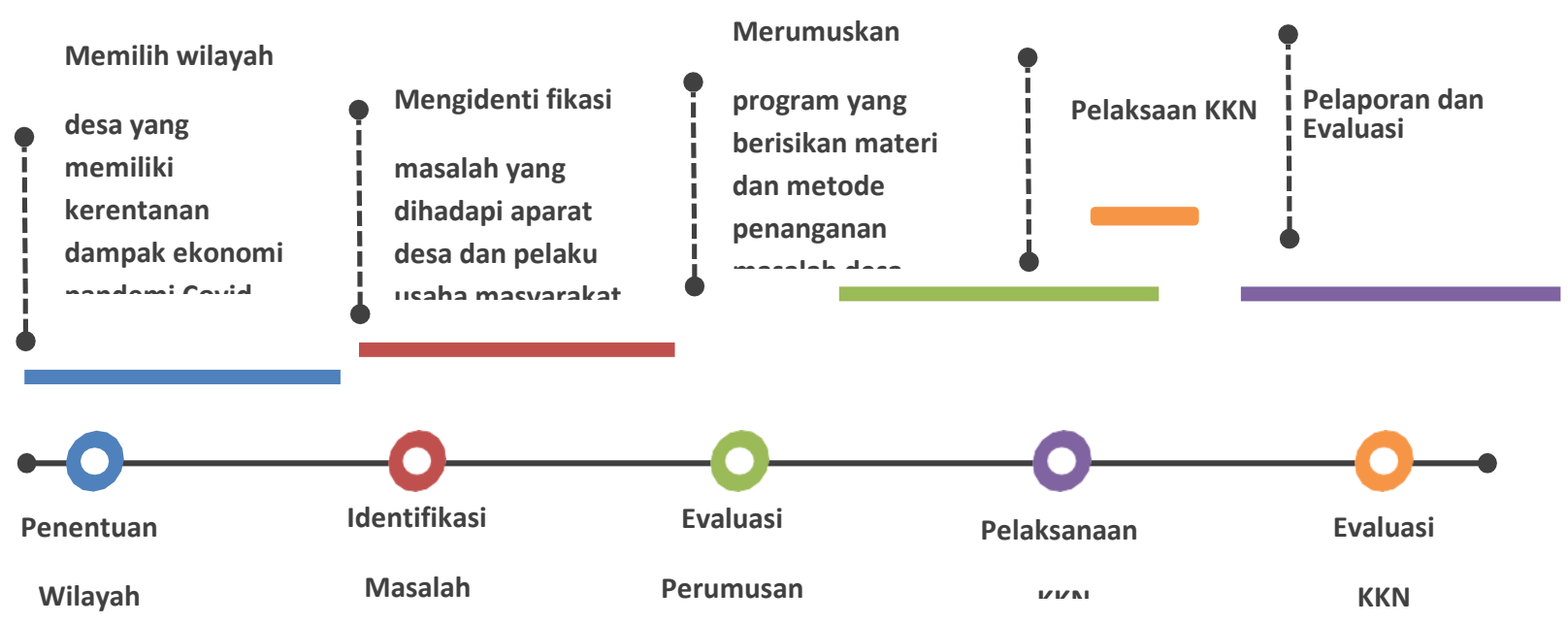

Gambar 3.1. Flowchart Kegiatan KKN Tematik 2020

Seluruh rangkaian kegiatan di atas dikerjakan oleh 30 orang mahasiswa peserta KKN selama 60 hari kalender termasuk kegiatan persiapan. Setiap mahasiswa memiliki jam kerja efektif (JKEM) rata-rata 151 jam per bulan. Jenis kegiatan, program dan JKEM dikemukakan dalam tabel 3.1 .

Tabel 3.1 Volume Pekerjaan

\begin{tabular}{|c|c|c|c|c|}
\hline No & Nama Pekerjaan & Program & $\begin{array}{l}\text { Volume } \\
\text { (JKEM) }\end{array}$ & Keterangan \\
\hline 1 & Sosialisasi dampak ekonomi Covid-19 & $\begin{array}{l}\text { Penangan penyebaran } \\
\text { covid-19 }\end{array}$ & 1430 & \\
\hline 2 & $\begin{array}{l}\text { Bimbingan pengintegrasian dokumen yang } \\
\text { memitigasi dampak ekonomi Covid- } 19 \text { bagi } \\
\text { pelaku usaha/masyarakat desa }\end{array}$ & $\begin{array}{l}\text { Pemberdayaan UMK pada } \\
\text { masa krisis covid- } 19\end{array}$ & 3150 & \\
\hline 3 & $\begin{array}{l}\text { Bimbingan penyusunan protokol kerja sehat } \\
\text { bagi masyarakat desa/pelaku } \\
\text { usaha semi-urban }\end{array}$ & $\begin{array}{l}\text { Pemberdayaan UMK pada } \\
\text { masa krisis covid- } \\
19\end{array}$ & 1430 & \\
\hline \multicolumn{3}{|c|}{ Total Volume Kegiatan } & 6,010 & \\
\hline
\end{tabular}

\section{Hasil dan Pembahasan}

Pelaksanaan kegiatan KKN tematik ini dilakukan secara terbatas dengan memperhatikan protokol kesehatan Covid-19 (menggunakan masker dan physical distancing). Pertama adalah melakukan pendataan penduduk dan interview kepada masyarakat dengan daftar pertanyaan. 


\section{A. Hasil pemetaan dari kuesioner kepada masyarakat}

Profil desa di Kecamatan Konda Kabupaten Konawe Selatan.

a. Pendataan karakteristik desa menurut jarak desa ke ibu kota dan potensi ekonomi desa

Desa Morome merupakan salah satu desa di Kecamatan Konda yang memiliki jarak terdekat ke Ibu Kota Kendari yaitu $3 \mathrm{Km}$ dan desa yang memiliki jarak terjauh dari kota Kendari yaitu Desa Laowila dengan jarak tempuh $15 \mathrm{Km}$. Potensi ekonomi desa yaitu pertanian, perkebunan, peternakan, produksi tahu tempe, pemasok sayuran, UMKM, dan pengembangan bumdes dan wisata.

b. Pendataan karakteristik masyarakat terdiri atas jumlah penduduk dan jenis pekerjaan

Kecamatan Konda memiliki penduduk sebanyak 29.075 orang. Jenis pekerjaan masyarakat Kecamatan Konda adalah sebagai petani, pekebun, berternak, pedagang sayur buruh dan lain sebagainya.

c. Pendataan fasilitas kesehatan

Untuk pelayanan kesehatan Konda untuk ketersediaan tenaga kesehatan, dokter, bidan, perawat, hanya beroperasi di Desa Tanea. Untuk fasilitas kesehatan desa di Kecamatan Konda ada satu puskemas yang terletak di Desa Tanea, ada 2 pustu yang terletak di Desa Cialam Jaya dan Desa Lalowiu sedangkan untuk posyandu hampir semua desa memilikinya. Adapun desa yang tidak memiliki posyandu yaitu Tanea, Masagena, Morome, dan Kelurahan Konda.

\section{d. Pendataan fasilitas ekonomi}

Di Kecamatan Konda terdapat satu pasar tradisional yang terletak di Desa Ambololi yang hanya beroperasi 2 hari dalam seminggu , yaitu di hari Kamis dan hari Minggu jam 06.00-09.00 pagi. Sedangkan pembelanjaan modern di Kecamatan Konda terdapat di 3 dari 15 desa yaitu desa Desa Puosu Jaya, Kelurahan Konda, dan Desa Tanea. Ada 2 bank dan pembiayaan di Kecamatan Konda yang terletak di Desa Puosu Jaya dan Lebo Jaya.

e. Pendataaan sarana prasarana pemerintah desa

Untuk sarana dan prasarana kantor /balai desa dan BPD sudah dimiliki oleh semua desa yang ada di Kecamatan Konda. Sedangkan untuk bumdes yang sudah berjalan dan mendapatkan profit baru Desa Lambusa. 


\section{B. Script kuesioner aparat desa yang terdisrupsi pandemi Covid-19 di Kecamatan Konda Kabupaten Konawe Selatan}

a) Bagaimana mekanisme penyusunan program dan kegiatan dalam PBDes setiap tahun?

Mekanisme penyusunan program dimulai dari musyawarah tingkat RT, lalu musyawarah dusun, kemudian melakukan MUSREMBANG desa, dalam musyawarah tersebut semua dusun mengajukan kebutuhan yang menjadi prioritas masing-masing dusun. Hasil musyawarah tersebut akan disimpulkan untuk dibawa ke Kecamatan sebagai usulan untuk didanai pada tahun berikutnya.

b) Bagaimana prioritas pembangunan desa dalam 3 tahun terakhir?

Prioritas pembangunan desa dalam 3 tahun terakhir yaitu pembangunan drainase, pengerasan jalan dan duiker serta penambahan rumah layak huni. Infrastruktur daerah yang sifatnya dasar yang menunjang aktivitas ekonomi masyrakat belum kepada fasilitas Kesehatan dan pendidikan.

c) Bagaimana pelaksanaan program dan kegiatan desa setelah adanya Covid-19?

1. Melakukan penyemprotan disinfektan ke rumah-rumah masyarakat, tempat ibadah, dan fasilitas umum lainnya.

2. Mematuhi peraturan pemerintah tentang social distancing (PSBB) dan penggunaan masker serta selalu menjaga kesehatan.

3. Pemasangan spanduk imbauan pencegahan covid-19

4. Penyaluran bantuan covid-19 yang dialokasikan untuk masyarakat yang terdampak covid-19 dari anggaran dana desa.

d) Bagaimana mekanisme penyusunan realokasi anggaran Covid-19?

Kecamatan konda memberikan arahan kepada kepala desa untuk membentuk tim relawan yang terdiri dari RT, kepala dusun, toko masyarakat, dan aparat desa untuk mendata orang-orang yang berhak diberikan dana covid-19. Semua itu merupakan hasil dari rapat seluruh tim relawan yang telah dimusyawarakan bersama. Mengikuti petunjuk dengan mengalokasikan anggaran $15 \%$ s/d 25\% dari pengguna anggaran dana desa. 
e) Bagaimana dengan aturan/regulasi dalam perencanaan dan penganggaran desa pascacovid$19 ?$

Peraturan/regulasi pemerintah dalam perencanaan dan penganggaran desa ditengah pandemi covid-19 mengacu pada Peraturan Kemendagri, Peraturan Menteri Keuangan, aturan pemerintah, dan PERBUB (Peraturan Bupati). Terkait kondisi pandemi, pemerintah desa mengalami keterlambatan dalam pendistribusian alokasi bantuan Covid bagi masyarakat setempat karena adanya keterlambatan petunjuk pelaksanaan yang tertuang di Peraturan Bupati.

f) Apa hambatan dalam realokasi dana untuk Covid

Hambatan pemerintah desa di Kecamatan Konda dalam penyusunan realokasi dana covid-19 ada pada regulasi pemerintah pusat dan instansi sosial yang berbeda-beda sehingga pemerintah desa mengambil tindakan untuk membuat kebijakan dalam mengalokasikan dana covid-19 kemasyarakat yang sangat terdampak, karena dalam pandemi seperti ini semua masyarakat merasakan dampak adanya covid-19.

\section{Simpulan}

- Tujuan dari diadakannya kuisioner yaitu untuk mengetahui kendala yang ada di seluruh Kecamatan Konda dan untuk mengetahui proses penyusunan RPJM Desa di masing-masing desa yang ada di Kecamatan Konda. Selain itu untuk mengetahui peran aktif dari aparatur desa terkait bantuan yang diberikan kepada seluruh masyarakat yang disebabkan oleh pandemi Covid-19 ini. KKN tematik ini sebetulnya mempunyai kegiatan inti yang akan dihadiri oleh seluruh aparatur desa yang ada di Kecamatan Konda.

- Output dari kegiatan pengabdian kepada masyarakat adalah "Modul Penyusunan Perencanaan dan Penganggaran desa yang memitigasi risiko ekonomi (keberlangsungan usaha masyarakat) akibat Covid-19”

\section{Ucapan Terima Kasih}

1. LPPM UHO yang telah mendukung terlaksananya pelaksanaan KKN Tematik

2. Ketua Ikatan Sarjana Ekonomi Indonesia (ISEI) Kendari sebagai pemateri.

3. Camat Konda Ibu Asdiana, SE dan jajaran aparatur Desa. 


\section{Daftar Pustaka}

Badan Nasional Penanggulangan Bencana (BNPB). 2014. Rencana Nasional Penanggulangan Bencana 2015-2019. Jakarta.

Badan Pusat Statistik Kabupaten Konawe Selatan. 2020. Konawe Selatan Dalam Angka 2019. Konawe Selatan.

Badan Pusat Statistik Kabupaten Konawe Selatan. 2020. Kecamatan Konda Dalam Angka 2019. Konawe Selatan.

Buchari, A.,Santoso, M.B., \& Marlina, N (2017). Pengembangan Kapasitas kelembagaan Desa Tangguh bencana di Kabupaten Garut (Studi Kasus di Desa pasawahan Kecamatan Tarogong Kaler). Jurnal Analisis dan kebijakan Publik. Vol.3 No 1. Juni 2017. Hal 49-62.

Maarif, Syamsul. (2015). Sosiologi Kebencanaan dan Pengurangan Risiko Bencana Komunitas (Pengukuhan Sebagai Guru Besar Sosiologi Kebencanaan), Jember; Universitas Jember.

Wikantiyoso, Respati, (2010). Mitigasi Bencana di Perkotaan: Adaptasi dan Antisipasi Perencanaan dan Perencanaan Kota? (Potensi Kearifan Lokal dalam Perencanaan dan Perancangan Kota Untuk Upaya Mitigasi Bencana). Local Wisdom. Vol. 2. No.1 Hal 18-19, Januari 2010.

Pratiwi, R. (2020), Dampak Penyebaran Virus Corona, https://www.rasio.co/dampakcovid-19-bagi-masyarakat/.

\section{LAMPIRAN}
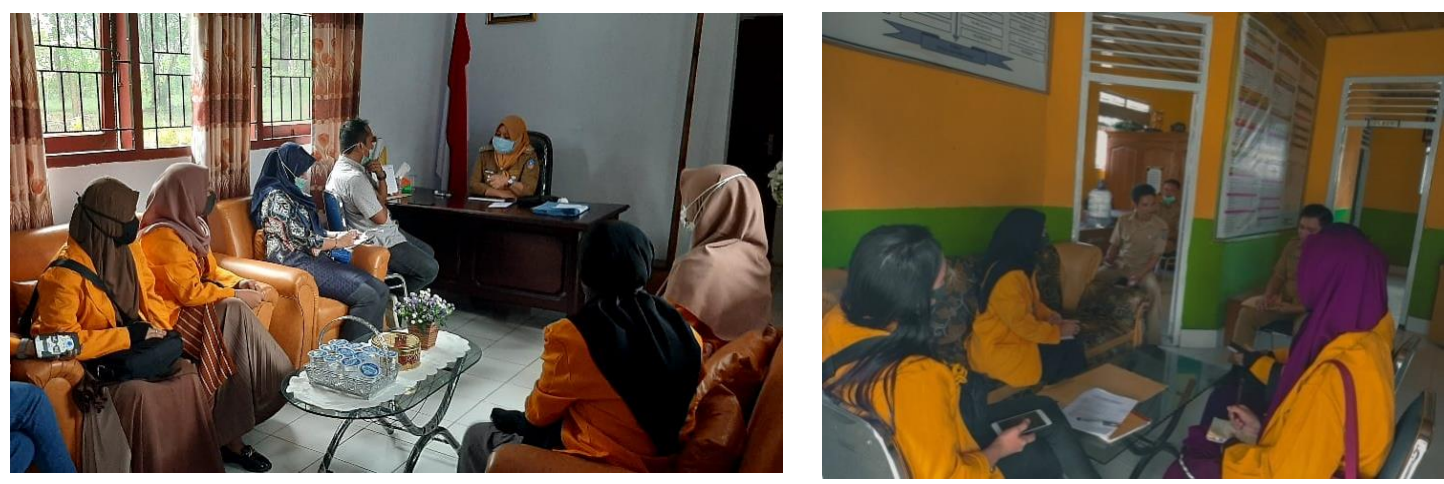

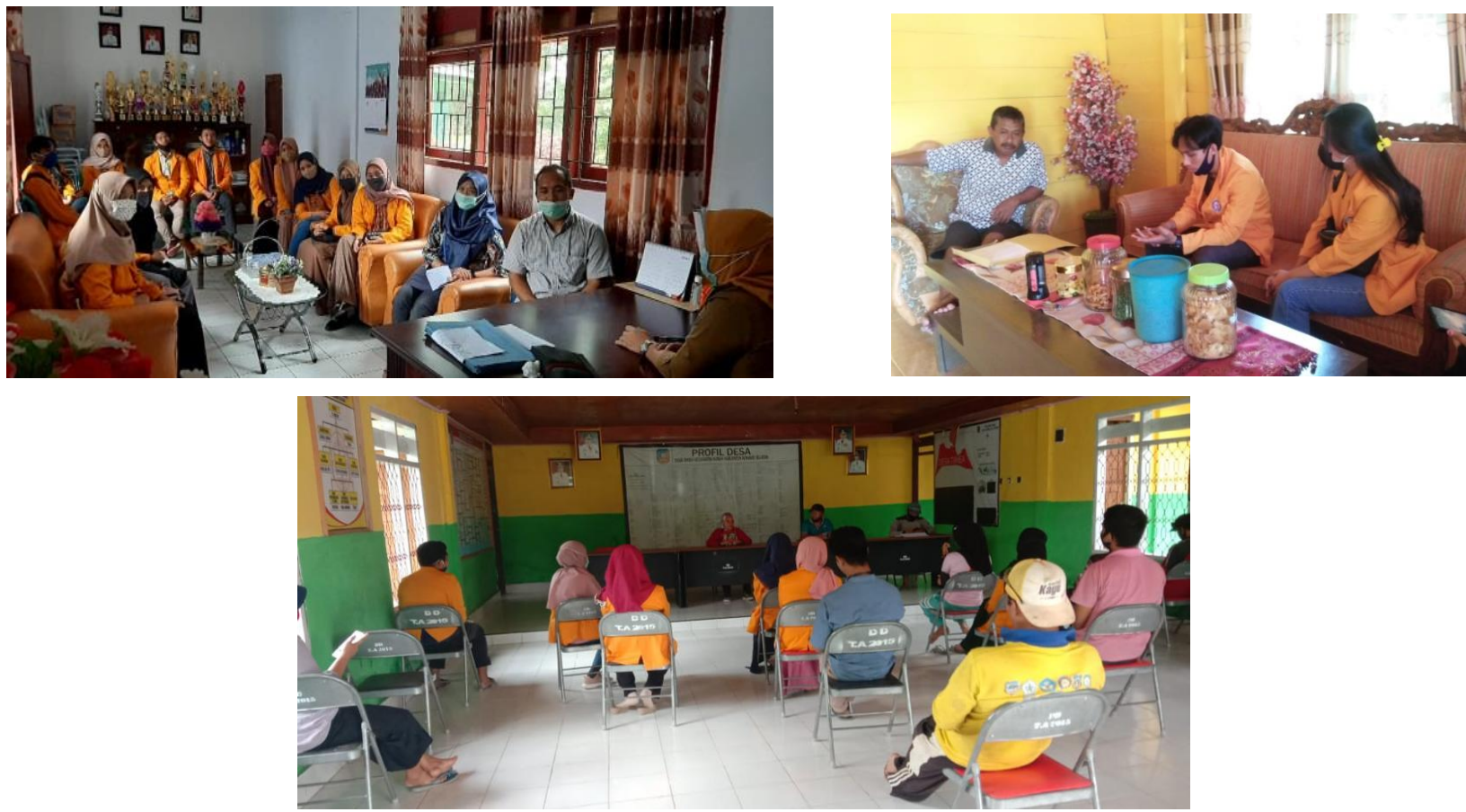

(Gambar 1.1 wawancara dan perkenalan aparat desa )

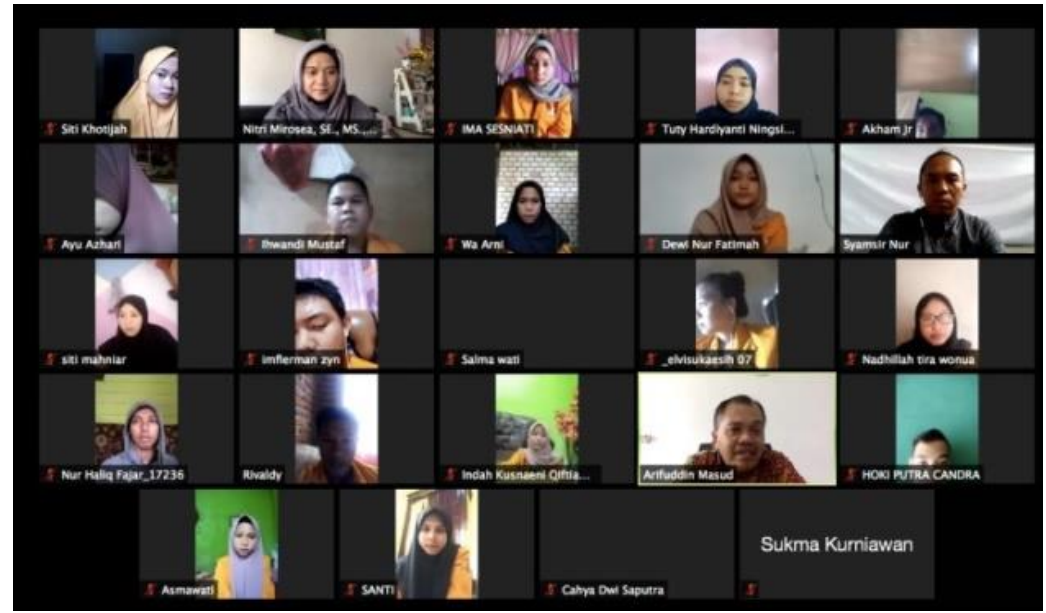

(Gambar 1.2 kegiatan pembekalan bersama ketua tim, DPL, dan peserta KKN Tematik melalui aplikasi zoom meeting) 

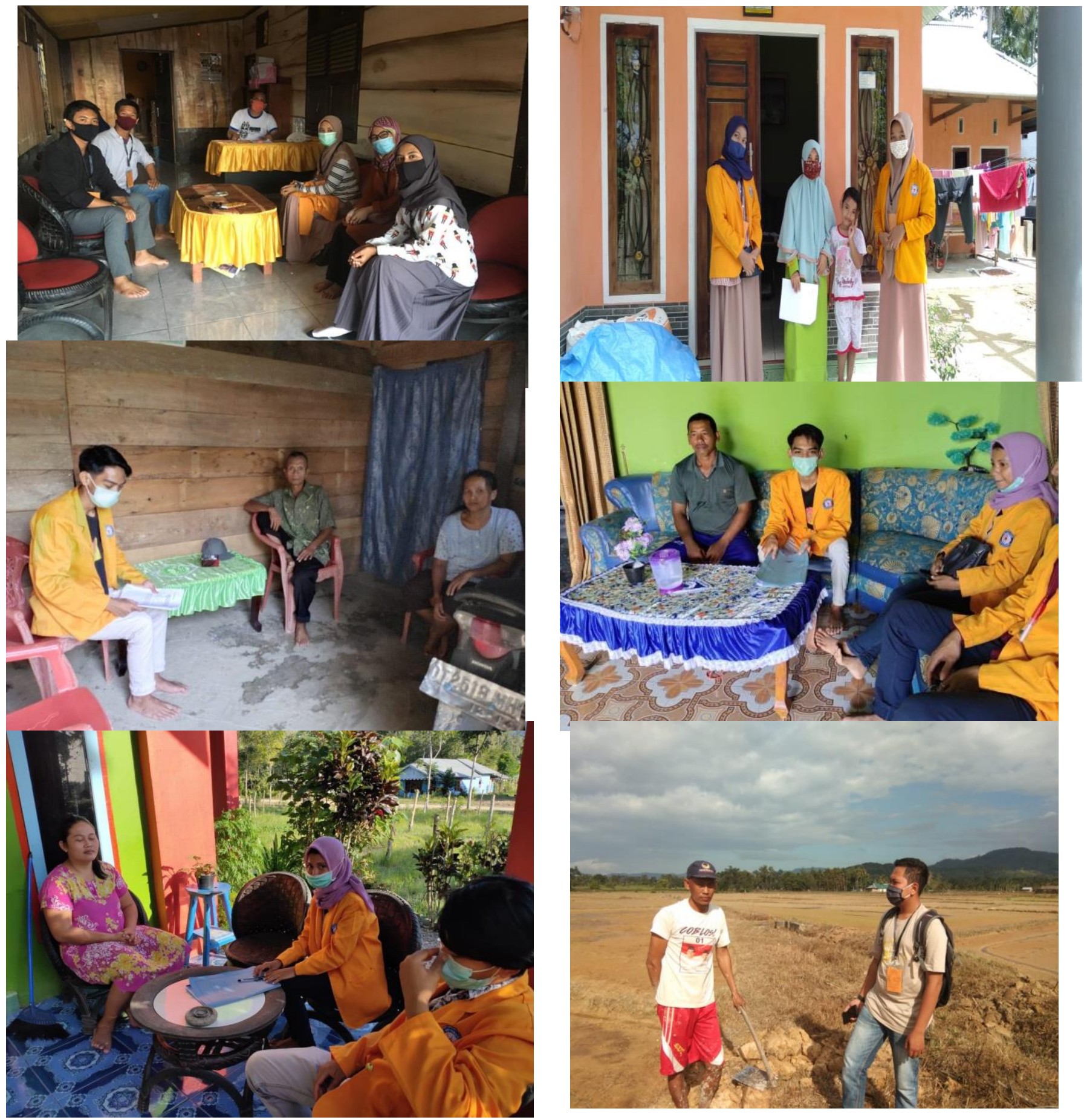
1305
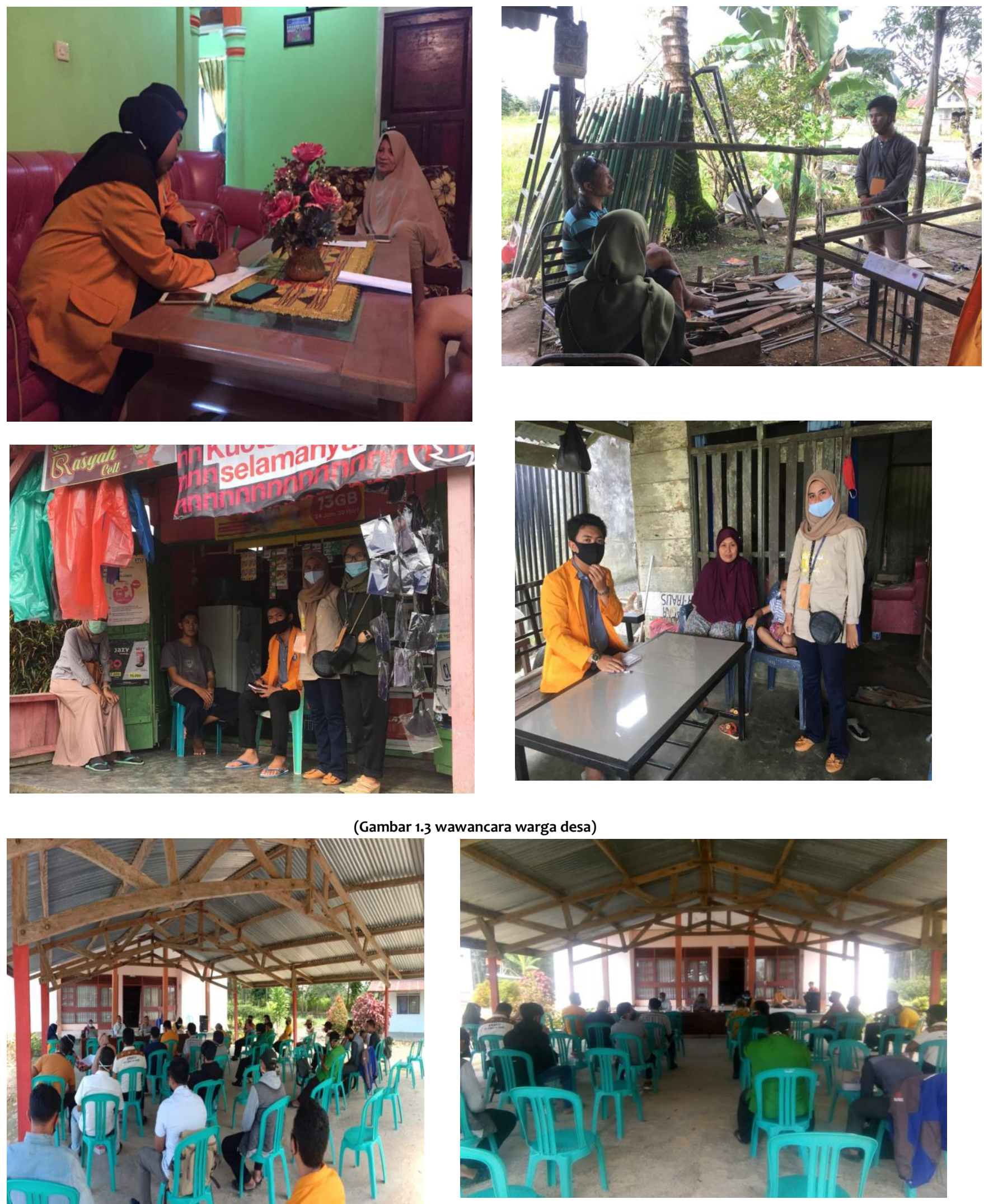
1306

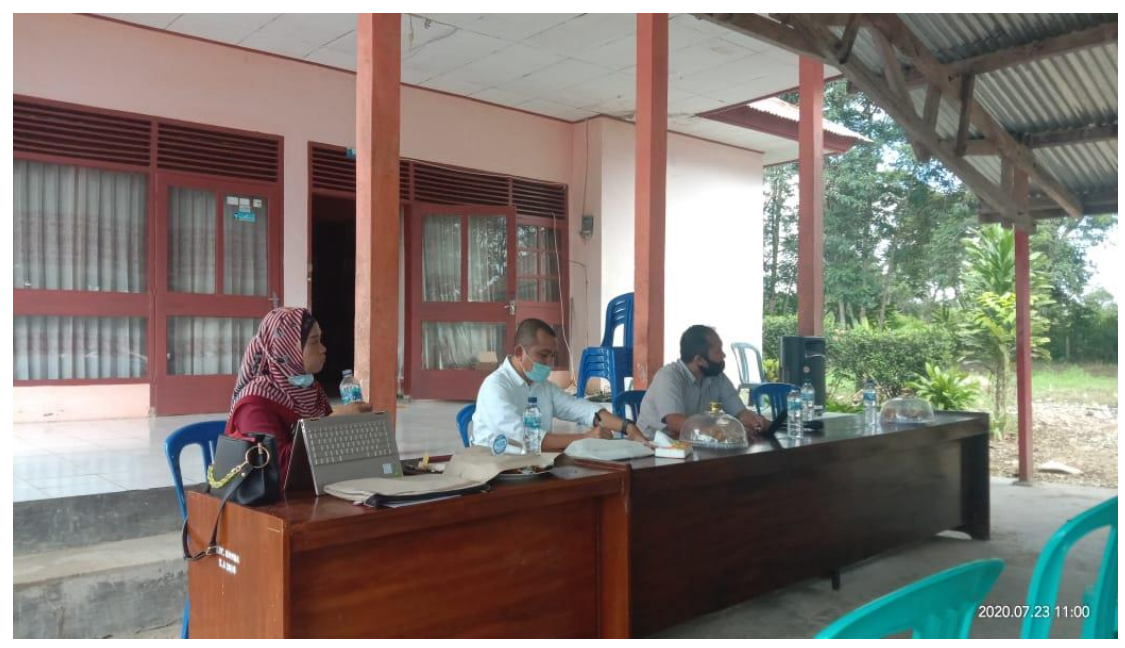

Gambar 1.4 Kegiatan program utama yaitu seminar pelatihan penyusunan RENBANGDES yang dihadiri oleh dekan FEBI UMK sekaligus dosen FEB UHO dan para aparat desa di Kecamatan Konda 